\title{
RANCANGAN PEMBELAJARAN TEMATIK TERPADU MATEMATIKA DAN MATA PELAJARAN LAIN DI SD/MI KELAS 1 BERDASAR KONSEP ISLAM SEBAGAI AGAMA HIJAU
}

\author{
Luluk Mauluah
}

Pendidikan Guru Madrasah Ibtidaiyah FITK UIN Sunan Kalijaga

Email: 1.mauluah@gmail.com

\begin{abstract}
ABSTRAK
Agama Islam disebut agama hijau karena sangat mempunyai perhatian tinggi terhadap kelestarian lingkungan. Dalam Alqur'an banyak ayat tentang pemeliharaan lingkungan yang disebut ayat hijau. Penamaan surah dalam Alqur'an: Al-Baqarah, An-Naml, An-Nahl, Al-Ankabut menggunakan nama-nama binatang. Kemudian hadits-hadits pun banyak yang merekomendasikan umat manusia untuk menjaga alam, menjaga lingkungan baik tanaman, maupun hewan. Hadits tersebut dapat disebut dengan hadits hijau. Konsep Islam sebagai agama hijau dapat digunakan dalam integrasi pembelajaran tematik terpadu. Pada tulisan ini integrasi dirancang untuk kelas 1 tema 7: Benda, Hewan dan Tanaman di Sekitarku. Pada Subtema 2: bacaan "Binatang Peliharaan Beni" dan bacaan "Tempat tinggal Hewan" sangat selaras dengan konsep Islam sebagai agama hijau. Demikian pula untuk subtema 3 dengan bacaan "Merawat Tanaman" sangat cocok dengan konsep Islam sebagai agama hijau. Pembelajaran matematika dengan pembelajaran tematik berdasar konsep Islam agama hijau dapat menggunakan peraga buah-buahan, biji-bijian dan melaksanakan pengukuran panjang pendek menggunakan pohon maupun bagianbagiannya.
\end{abstract}

Kata kunci: Islam sebagai agama hijau, pembelajaran tematik, ayat hijau, hadits hijau.

\begin{abstract}
Islam is called the religion of green because it has a high attention to environmental sustainability. In the Qur'an many verses concerning the preservation of the environment are called green verses. The naming of suras in the Qur'an: AlBaqarah, An-Naml, An-Nahl, Al-Ankabut using the names of animals. Then there are many hadiths that recommend humanity to maintain the nature, maintain good environment of plants, and animals. The hadith can be called by the green hadith. The concept of Islam as a green religion can be used in the integration of integrated thematic learning. In this paper the integration is designed for class 1 theme 7:
\end{abstract}


Benda, Hewan dan Tanaman di Sekitarku. In Subtema 2: the readings of "Binatang Peliharaan Beni" and the reading of "Tempat Tinggal Hewan" are very much aligned with the concept of Islam as a green religion. Similarly for subtheme 3 with the reading "Merawat Tanaman" fits perfectly with the concept of Islam as a green religion. Mathematical learning with thematic lessons based on the concept of green religion Islam can use fruits, grains and perform short length measurements using trees and parts.

\section{Keywords: Islam as a green religion, thematic learning, green verses, green hadith}

\section{A. PENDAHULUAN}

Islam memang agama rahmatallil'alamin. Tak hanya memberikan panduan agar bahagia di akhirat, tetapi Islam pun sangat peduli terhadap kelestarian alam. ${ }^{36}$ Istilah agama hijau muncul dari buku Green Deen ${ }^{37}$ yang ditulis Ibrahim Abdul Matin yang menjelaskan tentang bagaimana Islam mempunyai perhatian dan konsen untuk menyelamatkan planet/ bumi.

Di dalam Alqur'an terdapat ayat-ayat yang berkaitan dengan apresiasi Islam atau perintah untuk memelihara kelestarian alam, bumi, dan kehidupan. Ayat-ayat itu dapat digolongkan atau diistilahkan sebagai ayat-ayat hijau. Pun Rasulullah sendiri sangat merekomendasikan atas kepedulian terhadap lingkungan, terutama dalam menanam pohon, menjaga kebersihan, menyingkirkan sampah, dan lainnya. Hal ini dapat dipahami sebagai bentuk perhatian bahwa Islam dalam hal ini di hadits banyak memerintahkan untuk peduli pada lingkungan sekitar, yang mana muncul istilah hadits hijau, yaitu hadits yang memberi perhatian pada kelestarian dan keharmonisan lingkungan.

Pada era global ini, di mana perindustrian sudah sedemikian maju, teknologi semakin berkembang, maka dampak negatifpun tak

36 Rami Killawi: Sustainable Development in Islamic Perspective, (Dubai, 2014), hlm.2

37 Ibrahim Abdul Matin, Green Deen, Inspirasi Islam dalam Menjaga dan Mengelola Alam, terjemahan, (Jakarta 2012). terelakkan. Sehingga menjadi kebutuhan mutlak dan kesadaran yang terus dimunculkan bahwa perkembangan teknologi global harus diimbangi dengan kesadaran hidup mengantisipasi kehancuran alam. Maksudnya, dalam dekade perkembangan global ini, tetap harus diminimalisir akibat negatifnya, maupun terus diupayakan untuk mengurangi risiko buruk dari kemajuan zaman.

Sekarang sudah terus dikampanyekan tentanghidupsehat, secaraindividual, komunitas lokal, nasional maupun internasional. Dunia mulai peduli untuk mengadakan penelitianpenelitian yang berkaitan dengan kelestarian lingkungan. Produk-produk mulai diupayakan memenuhi kaidah 3 R: reduce, reuse, recycle yang maksudnya adalah mengurangi, menggunakan kembali, dan mengolah kembali atau daur ulang.

Bangsa Indonesia yang merupakan bagian dari bangsa-bangsa di dunia pun tidak mau ketinggalan. Dengan kurikulum 2013, diharapkan siswa dapat mengantisipasi perubahan global. Dengan menghadapi tantangan eksternal berupa arus globalisasi terutama masalah lingkungan hidup, kemajuan teknologi informasi, kebangkitan industri kreatif dan budaya, dan perkembangan pendidikan di tingkat internasional, maka diperlukan kurikulum yang dapat mempersiapkan kehidupan di masa kini maupun masa depan. 
Sangat jelas disebutkan ${ }^{38}$ bahwa tujuan kurikulum 2013 adalah untuk mempersiapkaan manusia Indonesia agar memiliki kemampuan hidup sebagai pribadi dan warga negara yang beriman, produktif, kreatif, inovatif, dan afektif serta mampu berkontribusi pada kehidupan bermasyarakat, berbangsa, bernegara dan peradaban dunia.

Berdasar tekad mulia tersebut, maka berdasar PP nomor 32 tahun 2013 tentang standar nasional pendidikan, muncul perubahan bahwa pembelajaran di kelas rendah dilakukan dengan pendekatan tematik terpadu atau tematik integratif. Yaitu mengintegrasikan berbagai kompetensi dari berbagai mata pelajaran dalam berbagai tema. Pelaksanaannya pada kelas I-III IPA diintegrasikan ke dalam bahasa Indonesia, sedangkan IPS pada PKn. Adapun kelas IV-VI IPA dan IPS muncul dalam kompetensi dasar tersendiri tetapi pelaksanaannya tetap dalam pembelajaran tematik terpadu. ${ }^{39}$

Pendidikan sejak dini atau pada usia awal merupakan hal yang sangat penting dan memberikan bekas yang nyata. Berdasar beberapa penilaian capaian anak-anak Indonesia oleh TIMSS (Trends in International Mathematics and Science Study), terdapat hasil yang kurang menggembirakan, maka perlu didorong adanya pembelajaran terpadu antara matematik dan sains yang memacu prestasi dan pemahaman secara menyeluruh ditambah kesadaran pada alam sekitar. Mengingat hal tersebut, maka semangat Islam sebagai agama hijau dapat diimplementasikan pada pembelajaran matematika dan sains yang tematik terpadu dan terintegrasi.

38 Permen no 57 tahun 2014 tentang kurikulum 2013 SD/MI; lampiran hlm. 3

39 Permen no 57 tahun 2014 tentang kurikulum 2013 SD/MI; lampiran hal 218

\section{B. PEMBAHASAN}

\section{Pembelajaran Tematik Terpadu}

Proses pembelajaran pada kurikulum 2013 mengalami perubahan, yaitu: ${ }^{40}$ sesuai dengan Standar Kompetensi Lulusan dan Standar Isi maka prinsip pembelajaran yang digunakan adalah:

1. dari peserta didik diberi tahu menuju peserta didik mencari tahu;

2. dari guru sebagai satu-satunya sumber belajar menjadi belajar berbasis aneka sumber belajar;

3. dari pendekatan tekstual menuju pendekatan proses sebagai penguatan penggunaan pendekatan ilmiah;

4. dari pembelajaran berbasis konten menuju pembelajaran berbasis kompetensi;

5. dari pembelajaran parsial menuju pembelajaran terpadu;

6. dari pembelajaran yang menekankan jawaban tunggal menuju pembelajaran dengan jawaban yang kebenarannya multi dimensi;

7. dari pembelajaran verbalisme menuju keterampilan aplikatif;

8. peningkatan dan keseimbangan antara keterampilan fisikal (hardskills) dan keterampilan mental (softskills);

9. pembelajaran yang mengutamakan pembudayaan dan pemberdayaan peserta didik sebagai pembelajar sepanjang hayat;

10. pembelajaran yang menerapkan nilainilai dengan member keteladanan(ing ngarso sung tulodo), membangun kemauan (ing madyomangun karso),

$40 \quad$ Salinan lampiran Permendikbud RI no 65 thn 2013 tentang standar proses pendidikan dasar dan menengah 
dan mengembangkan kreativitas peserta didik dalamproses pembelajaran (tut wuri handayani);

11. pembelajaran yang berlangsung di rumah, di sekolah, dan di masyarakat;

12. pembelajaran yang menerapkan prinsip bahwa siapa saja adalah guru, siapa saja adalah siswa, dan di mana saja adalah kelas.

13. Pemanfaatan teknologi informasi dan komunikasi untuk meningkatkan efisiensi dan efektivitas pembelajaran; dan

14. Pengakuan atas perbedaan individual dan latar belakang budaya peserta didik.

Berdasar prinsip-prinsip tersebut, disusunlah kurikulum tematik, yaitu kurikulum yang memuat konsep pembelajaran terpadu yang menggunakan tema untuk mengaitkan beberapa mata pelajaran sehingga dapat memberikan pengalaman bermakna pada para peserta didik $^{41}$. Dengan pembelajaran tematik ini akan terdapat beberapa keunggulan yang diperoleh yaitu: ${ }^{42}$ dapat mengurangi overlapping antara berbagai mata pelajaran, karena mata pelajaran disajikan dalam satu unit; menghemat pelaksanaan pembelajaran terutama dari segi waktu, karena pembelajaran tematik dilaksanakan secara terpadu antara beberapa mata pelajaran; anak didik mampu melihat hubunganhubungan yang bermakna sebab materi lebih berperan sebagai sarana atau alat, bukan tujuan akhir; pembelajaran menjadi holistik

41 Ibnu Hajar, Panduan Lengkap Kurikulum Tematik untuk SD/MI (Yogyakarta: Diva Press, 2013), hlm. 21

42 Abd Kadir dan Hanun Asrohah, Pembelajaran Tematik (Jakarta :PT Raja Grafindo Persada, 2014), hlm. 26 dan menyeluruh sehingga anak didik akan mendapat pengertian mengenai proses dan materi yang saling berkaitan antara satu dengan yang lain; keterkaitan antara satu mata pelajaran dengan lainnya akan menguatkan konsep yng telah dikuasai anak didik, karena didukung dengan pandangn dari berbagai perspektif.

Namun, di balik keunggulannya, terdapat pula kelemahan pembelajaran tematik yaitu:43 pembelajaran menjadi lebih kompleks dan menuntut guru untuk mempersiapkan diri sedemikian rupa supaya ia dapat melaksanakannya dengan baik; persiapan yang harus dilakukan oleh guru pun lebih lama; guru harus merancang pembelajaran tematik dengan memerhatikan keterkaitan antara berbagai pokok materi tersebar di beberapa mata pelajaran; menuntut penyediaan alat, bahan, sarana dan prasarana untuk berbagai mata pelajaran yang dipadukan secara serentak.

Mengingat pelaksanaan pembelajaran tematik yang tidak sederhana, guru perlu memperhatikan beberapa hal sebagai berikut. ${ }^{44}$ Perlu melakukan pembelajaran awal yang menggugah rasa ingin tahu, pemberian pengantar antara sub tema sangat penting untuk mengaitkan dan menghubungkan. Menggunakan ide-ide kreatif terutama jika keadaan tidak sesuai dengan buku guru atau buku siswa.

\section{Konsep Islam sebagai Agama Hijau}

Kepedulian terhadap perkembangan lingkungan dimulai saat Majelis Umum PBB menyelenggarakan Konferensi di Stockholm, Swedia pada 6 Juni 1972,

$\overline{43 \quad \text {.......hlm. 26-27 }}$

44 BSE, Buku tematik Kelas 1 (2013), hlm. v 
yang sekarang diperingati sebagai Hari Lingkungan Hidup Sedunia. ${ }^{45}$ Setelah itu, diselenggarakan pula KTT Bumi oleh PBB di Rio de Janeiro yang membahas tema sentral Sustainable Development atau pembangunan yang berkelanjutan. ${ }^{46}$

Sejak saat itu, bermunculan istilah menggunakan kata green, seperti green accounting atau envoromental accounting. ${ }^{47}$ Lalu ada istilah green environmental philosophy, ${ }^{48}$ green COM, ${ }^{49}$ Green Deen, Inspirasi Islam dalam Menjaga dan Mengelola Alam $^{50}$, Greenships Existing Building, Green Building Council Indonesia, ${ }^{51}$ dan juga istilah Green business. ${ }^{52}$ Semua kata green itu mempunyai makna berkaitan dengan kepedulian lingkungan.

Rami Killawi dalam tulisannya: Sustainable Development in Islam

45 Agung Prihatmiko, “Akuntasi Hijau: Penelaahan atas Akuntansi Biaya Lingkungan" (Jakarta: Skripsi STAN 1994) hlm. 34

46 ...ibid, hlm. 34

47 John P Surma dan Albert A. Vondra, "Accounting for Environmental Cost, a Hazardous Subject." Journal of Accountancy (Maret 1992), hlm. 51

48 Kamaruzaman Jusoff dan Siti Akmar Abu Samah, "Environmentl Sustainability: What Islam Propagates," World Applied Sciences Journal 12 (Special Issue on Creating a Knowledge Based Society), (2011), hlm. 47

49 Office of Sustainable Development Bureau for Africa, Lessons From School-Based Environmental Education Programs in Three African Countries (Mfuwe, Zambia, 2000), hlm. 3

50 Ibrahim Abdul Matin, Green Deen, Inspirasi Islam dalam Menjaga dan Mengelola Alam, terjemahan, (Jakarta 2012), hlm 1

51 Green Building Council Indonesia, Green Rating Tools untuk Gedung Terbangun Versi 1.0, (Jakarta, 2011), hlm. 1

52 SWA, Green Business Great Profit; (Maret 2016), hlm. 1
Perspective menyatakan:

...’'Islam, as a religion of civilization, provides guidance and advice towards the happiness of humanity, and hence it cares for the issue of Sustainable Development....." 53

Maksudnya adalah bahwa Islam sebagai agama dari peradaban, menyediakan pedoman dan tuntunan untuk menuju kebahagiaan umat, sehingga pastilah peduli terhadap pembangunan yang berkelanjutan. Sejak ratusan tahun silam, Islam telah waspada memperingatkan melalui firmanNya: “...Telah tampak kerusakan di darat dan di laut disebabkan oleh perbuatan tangan manusia, (Allah menunjukkan ini semua) supaya mereka merasakan sebagian dari (akibat) perbuatannya agar mereka kembali (ke jalan yang benar).” (QS. 30: 41)

Ini menjelaskan bahwa Islam sangat memperhatikan perkembangan lingkungan hidup. Istilah Pembangunan Berkelanjutan atau Sustainable Development mengemuka saat dilaksanakan Second Earth Summit in Johannesburg, South Africa in 2002 titled "The International Summit for Sustainable Development". ${ }^{54}$ Dalam acara tersebut dimaknakan bahwa Pembangunan Berkelanjutan adalah pembangunan yang mengelaborasikan antara generasi sekarang dengan generasi yang akan datang, terutama dalam mewariskan sumber daya alam secara adil. Tujuannya adalah untuk meningkatkan kualitas standar hidup untuk populasi dunia, dan menentukan ukuran kesehatan, tempat

53 Rami Killawi, Sustainable Development in Islamic Perspective, (2014), hlm. 4

54 Ibid, hlm 10-11 
tinggal yang layak dan kemakmuran untuk setiap individual. ${ }^{55}$

Dan sungguh tampak dalam Alqur'an bahwa Islam sangat peduli terhadap lingkungan. Coba perhatikan nama-nama surat dalam Alqur'an sangat dekat dengan lingkungan hidup manusia. Rami Killawi menyatakan: ${ }^{56}$

"...Surahs carrying the names of insects like The Bees, The Ants, and The Spider. Some carried the names of minerals like The Iron, or plants like The Figs. Many ayah or verses talk about natural phenomena such as thunder, mountains, rocks, trees. How does that relate to the topic of environment? ..."

Maksudnya, tampak jelas bahwa Alqur'an dinamai dengan nama serangga: Lebah (An-Nahl), Semut (An-Naml), Laba-laba (Al-Ankabut), dan Alqur'an menggunakan mineral: Besi (Al-Hadid) atau tanaman yaitu buah Tin (At-Tin). Tinjauan lain terkait Islam sebagai agama hijau, atau istilah Ibrahim Abdul Matin, Green Deen: Konsep Agama Hijau mengajak umatnya untuk menegaskan hubungannya secara integral antara keimanan dengan lingkungan atau dengan seluruh alam semesta. ${ }^{57}$

Adapun Menurut Ibrahim Abdul Matin, ada 6 prinsip yang terkandung pada Islam sebagai Agama Hijau, yaitu: ${ }^{58}$ 1) Memahami kesatuan antar Tuhan dan ciptaan-Nya tauhid), 2) Melihat tanda-tanda/ ayat Tuhan di mana saja, 3) Menjadi penjaga/ Khalifah

\section{$55 \quad$ Ibid, hlm 11}

56 Ibid, hlm 25

57 Ibrahim Abdul Matin, Green Deen, (terjemhan, Jakarta, 2002), hlm. 22

58 Ibid. hlm. 25 di muka bumi, 4) Menjaga kepercayaan Tuhan/ amanah, 5) Berjuang menegakkan keadilan/ adl, dan 6) Menjalani kehidupan yang seimbang dengan alam/ mizan. Berdasar 6 prinsip tersebut, Ibrahim Abdul Matin konsen pada pembahasan tentang energi, air dan makanan. ${ }^{59}$

Penjelasan lebih lanjut tentang Islam sebagai agama hijau, dapat diuraikan pada 10 Green Quran Ayat/ Quran Verses on the Environment ${ }^{60}$ sebagai berikut. 1). Anti Corruption Police: QS 28:77; QS. 2:60. 2) Call Yourself Human? QS. 33:72, QS 6:165 3). Ending Poverty: QS. 89: 18, QS. 89: 17 4) Preservation of Water: QS. 16:65, QS. 50: 9. 5) Gardens of Paradise: QS 6: 99. The plants mentioned in Quran: garlic, grapes, pomagranate, herbs, dates, ginger, olives, lentils, onion, cucumber, figs, mustard, a variety of trees: cedar, acacia. 6) Treating Animals with Dignity: QS. 6:38. 7) Eating Wholesome: QS 2: 60. 8) Patching the Ozone: QS. 21:32, QS. 40: 64.9) Understanding the Creation: QS. 39::21, QS. 16:51, QS. 55: 19-20. QS. 7:57, QS. 30:48, QS 13: 12. 10) Respecting the Creator: $Q .17: 110$.

Kemudian dapat dikemukakan pula tentang Islam sebagai agama hijau melalui hadits hijau sebagai berikut. 10 Green Ahadith, Ecological Advice From Prophet Muhammad $^{61}$

1) A Believer is like a Growing tree: "The example of a believer is that of a fresh tender plant; from whatever direction the wind comes, it bends it, but when the

59 .....Ibid: hlm. 123, 181, dan 223

60 www.theecomuslim.com disunting pada 10 Juli 2017 pukul 14.15

61 www.theecomuslim.com disunting pada 23 Juli 2016 pukul 08.00 
wind quietens down, the plant becomes straight again..." narrated by Abu Hurayra, Bukhari

2) Plant a tree event it's your last deed: "If the Hour (the day of Resurrection) is about to be established and one of you was holding a palm shoot, let him take advantage of even one second before the Hour is established to plant it." - AlAlbani.

3) Planting trees is a renewable source of reward

"If a Muslim plants a tree or sows seeds, and then a bird, or a person or an animal eats from it, it is regarded as a charitable gift (sadaqah) for him." - Imam Bukhari

4) Conserve resources even when used for routine rituals Prophet Muhammad, peace and blessings be upon him, happened to pass by a Companion, Sa'd, as he was performing ablution (wudhu) next to a river. At this, the Prophet said, "Sa'd what is this squandering?" Sa'd replied: "Can there be an idea of squandering (israf) in ablution?" The Prophet said: "Yes, even if you are by the side of a flowing river." - Ibn Majah.

5) Keeping the environment sanitary maintains the community "Beware of the three acts that cause you to be cursed: [1] relieving yourselves in shaded places (that people utilise), in a walkway or in a watering place." - Narrated by Mu'adh, hasan, by Al-Albani

Hygiene and cleanliness (tahara) is so integral to Islam that it is actually a major sub-branch of Muslim belief. Without physical hygiene, prayers are broken. Without clean facilities pollution ruins cities, and without any effort to improve one's own purity, it becomes more difficult to prevent external corruptions like littering.

6) Thus, Prophet Muhammad said about street clean-ups,

"Removing harmful things from the road is an act of charity (sadaqah)." Narrated by Abu Dharr Al-Ghafari.

7) Say no to over-consumption (or at least reduce it)

Abdullah ibn 'Abbas reported that the Prophet said, "The believer is not he who eats his fill while his neighbor is hungry." Authenticated by Al-Albani

8) Eat a little less every day

Excessive eating is abhorred in Islam. For the days of Ramadan, fasting is precisely a command in order to learn control and when to say 'no'. Prophet Muhammad did not encourage eating a three course meal nor a heavy meal. Every meal should be shared between two and choosing between take-outs and home-cooked, a healthier diet is always the better option (less meat, more greens). In the Islamic law system (Shariah), a person should stop eating as soon as the hunger pangs cease.

"Nothing is worse than a person who fills his stomach. It should be enough for the son of Adam to have a few bites to satisfy his hunger. If he wishes more, it should be: One-third for his food, one-third for his liquids, and one-third for his breath." Tirmidhi and Ibn Majah.

9) Consider recycling and fixing before buying new items

When asked about how the Prophet used 
to live in his house, the Prophet's wife, 'A'ishah, said that he used to repair his own shoes, sew his clothes and carry out all such household chores done without complaint or want for more. (Authenticated by Al-Albani).

The idea behind this was to show Muslims that menial tasks (mehna) were not degrading for God's Prophet. Reusing and repairing things instead of always buying new is not a sign of poverty, they are a sign of power. By performing household duties, the Prophet was saying we can build foundations on less 'stuff', we are in control of what we consume and we don't need more.

10)Animals should be cared for:

"A man felt very thirsty while he was on the way, there he came across a well. He went down the well, quenched his thirst and came out. Meanwhile he saw a dog panting and licking mud because of excessive thirst. He said to himself, "This dog is suffering from thirst as I did." So, he went down the well again, filled his shoe with water, held it with his mouth and watered the dog. Allah appreciated him for that deed and forgave him." The Companions said, "O Allah's Messenger! Is there a reward for us in serving the animals?" He replied: "There is a reward for serving any living being."

- Imam Bukhari.

\section{Pembelajaran Tematik Terpadu}

Matematika dan Mata Pelajaran Lain untuk Kelas 1 SD/MI

Cagne dan Biggs menyatakan bahwa pembelajaran adalah rangkaian peristiwa/ kejadian yang mempengaruhi siswa sedemikian rupa sehingga proses belajarnya dapat berlangsung dengan mudah. Jadi pembelajaran adalah suatu aktivitas yang disengaja untuk memodifikasi berbagai kondisi yang diarahkan untuk tercapainya tujuan, yaitu tujuan kurikulum. ${ }^{62}$ Pembelajaran dipandang sebagai suatu sistem, di dalamnya melibatkan berbagai komponen. Paling tidak terdapat empat komponen dalam pembelajaran, yaitu: tujuan pembelajaran, materi/ bahan pengajaran, metode dan alat yang digunakan, dan penilaian. ${ }^{63}$

Pendapat Reys et. $\mathrm{al}^{64}$ :

"...Mathematics is a study o patterns and relationships, is a way of thinking, is an art, is a language, and is a tool...."

Maksudnya, Reys dan kawan-kawan menyatakan bahwa matematika adalah telaah dan kajian tentang pola dan hubungan, suatu jalan atau cara berpikir, suatu seni, suatu bahasa dan suatu alat.

Adapun Kline menjelaskan bahwa matematika bukanlah pengetahuan menyendiri yang dapat sempurna karena dirinya sendiri tetapi adanya matematika itu terutama untuk membantu manusia memahami dan mengetahui masalah sosial, ekonomi dan alam. ${ }^{65}$

Berdasar uraian tentang matematika dan pembelajarannya, maka dapat dirumuskan

62 Tengku Zahara Djafar (2001), Kontribusi Strategi Pembelajaran Terhadap Hasil Belajar (Jakarta: Balitbang Depdiknas, 2001), hlm. 2

63 Nana Sudjana. (1989) Teknologi Pengajaran (Bandung: Sinar Ilmu, 1989), hlm. 30

64 Reys et al, Helping children learn mathematics. (Fifth edition; Boston: Allyn and Bacon, 1998), hlm.2

65 Opcite, hlm. 17 
bahwa pembelajaran matematika adalah aktivitas pembelajaran yang meliputi 4 komponen, yaitu tujuan pembelajaran, materi/ bahan pengajaran, metode dan alat yang digunakan, dan penilaian untuk matematika sebagai ilmu deduktif, abstrak dan konsisten.

\section{Pembelajaran Tematik Kelas 1 Tema 7}

Penerapan konsep Islam sebagai agama hijau akan lebih mudah jika pembelajaran matematika diintegrasikan dengan mata pelajaran yang lain. Untuk itu akan dibahas rancangan pembelajaran tematik terpadu matematika dengan mata pelajaran lain, dibatasi pada materi kelas 1 SD/MI. Pada level kelas 1 ini, dibatasi untuk tema 7: Benda, Hewan, dan Tanaman di Sekitarku. Hal ini sangat sesuai dengan bahasan Ayat hijau dan hadits hijau yang telah menyebut nama-nama hewan, benda/ mineral dan tumbuhan/ tanaman yang menjadi namanama surat maupun menjadi ayat dan hadits dalam Islam yang menunjukkan perhatian Islam terhadap kelestarian lingkungan.

Tema 7 ini memuat 4 subtema $^{66}$ yaitu terdiri dari Subtema 1: Benda Hidup dan Tak Hidup di Sekitar kita; Subtema 2: Hewan di Sekitarku; Subtema 3: Tanaman di Sekitarku; Subtema 4: Bentuk, Warna, Ukuran dan Permukaan Benda. Pada Tema 7 ini memuat Kompetensi Inti sebagai berikut. ${ }^{67}$

1. Menerima dan menjalankan ajaran agama yang dianutnya.

66 Sonya Sinyanyuri dan Lubna Assagaf, Buku Tematik Terpadu Kurikulum 2013 Tema 7, Buku Siswa SD/MI Kelas 1 (Jakarta, Kementrian Pendidikan dan Kebudayaan, 2016), hlm. vi

67 Buku Guru Buku Tematik Terpadu Kurikulum 2013 Tema 7, Buku Guru SD/MI Kelas 1 (Jakarta: Kementrian Pendidikan dan Kebudayaan, 2016) hlm. xi
2. Memiliki perilaku jujur, disiplin, tanggung jawab, santun, peduli, dan percaya diri dalam berinteraksi dengan keluarga, teman, dan guru.

3. Memahami pengetahuan faktual dengan cara mengamati [mendengar, melihat, membaca] dan menanya berdasarkan rasa ingin tahu tentang dirinya, makhluk ciptaan Tuhan dan kegiatannya, dan benda-benda yang dijumpainya di rumah dan di sekolah.

4. Menyajikan pengetahuan faktual dalam bahasa yang jelas dan logis, dalam karya yang estetis, dalam gerakan yang mencerminkan anak sehat, dan dalam tindakan yang mencerminkan perilaku anak beriman dan berakhlak mulia.

Adapun kompetensi dasar untuk tiaptiap subtema adalah sebagai berikut. ${ }^{68}$

68 Ibid, hlm. 1 


\begin{tabular}{|c|c|c|}
\hline SUBTEMA 1 & KI 1 & KI 2 \\
\hline PPKn & $\begin{array}{l}\text { 1.2 Menerima kebersamaan dalam } \\
\text { keberagaman sebagai anugerah } \\
\text { Tuhan Yang Maha Esa di lingkungan } \\
\text { rumah dan sekolah }\end{array}$ & $\begin{array}{l}\text { 2.3 Menunjukkan perilaku kebersamaan dalam } \\
\text { keberagaman di rumah dan sekolah }\end{array}$ \\
\hline Matematika & & $\begin{array}{l}\text { 2.1 Menunjukkan sikap cermat dan teliti, tertib } \\
\text { dan mengikuti aturan, peduli, disiplin } \\
\text { waktu, serta tidak mudah menyerah dalam } \\
\text { mengerjakan tugas }\end{array}$ \\
\hline SBDP & & $\begin{array}{l}\text { 2.2 Menunjukkan rasa ingin tahu untuk } \\
\text { mengenal alam di lingkungan sekitar } \\
\text { sebagai sumber ide dalam berkarya seni } \\
\text { 2.3 Menunjukkan perilaku disiplin, tanggung } \\
\text { jawab dan kepedulian terhadap alam sekitar } \\
\text { melalui berkarya seni }\end{array}$ \\
\hline PJOK & & $\begin{array}{l}\text { 2.4 Menunjukkan kemauan bekerja sama } \\
\text { dalam melakukan berbagai aktivitas fisik } \\
\text { 2.5 Toleransi dan mau berbagi dengan teman } \\
\text { lain dalam penggunaan peralatan dan } \\
\text { kesempatan }\end{array}$ \\
\hline B Indonesia & $\begin{array}{l}\text { 1.1 Menerima anugerah Tuhan Yang } \\
\text { Maha Esa berupa bahasa Indonesia } \\
\text { yang dikenal sebagai bahasa } \\
\text { persatuan dan sarana belajar di } \\
\text { tengah keberagaman bahasa daerah }\end{array}$ & $\begin{array}{l}\text { 2.1 Memiliki kepedulian dan rasa ingin tahu } \\
\text { terhadap keberadaan wujud dan sifat benda } \\
\text { melalui pemanfaatan bahasa Indonesia dan/ } \\
\text { atau bahasa daerah }\end{array}$ \\
\hline
\end{tabular}

Untuk kompetensi dasar dari KI 3

dan KI 4 adalah sebagai berikut. ${ }^{69}$

\begin{tabular}{|c|c|c|}
\hline SUBTEMA 1 & KI 3 & KI 4 \\
\hline Matematika & $\begin{array}{l}\text { 3.2 Mengenal bilangan asli sampai } 99 \\
\text { dengan menggunakan benda-benda } \\
\text { yang ada di sekitar rumah, sekolah, } \\
\text { atau tempat bermain } \\
\text { 3.4 Menunjukkan pemahaman tentang } \\
\text { besaran dengan menghitung maju } \\
\text { sampai } 100 \text { dan mundur dari } 20 \\
\text { 3.10 Membandingkan dengan } \\
\text { memperkirakan berat suatu benda } \\
\text { menggunakan istilah sehari-hari } \\
\text { (lebih berat, lebih ringan) } \\
\text { 3.11 Membandingkan dengan } \\
\text { memperkirakan panjang suatu } \\
\text { benda menggunakan istilah sehari- } \\
\text { hari (lebih panjang, lebih pendek). }\end{array}$ & $\begin{array}{l}\text { 4.3 Mengemukakan kembali dengan kalimat } \\
\text { sendiri dan memecahkan masalah yang } \\
\text { berkaitan dengan penjumlahan dan } \\
\text { pengurangan terkait dengan aktivitas } \\
\text { sehari-hari serta memeriksa kebenarannya } \\
\text { 4.4 Mendeskripsikan, mengembangkan, dan } \\
\text { membuat pola yang berulang } \\
\text { 4.8 Mengelompokkan teman sekelas } \\
\text { berdasarkan tinggi badannya }\end{array}$ \\
\hline
\end{tabular}

69 Buku Guru Buku Tematik Terpadu Kurikulum 2013 Tema 7, Buku Guru SD/MI Kelas 1 (Jakarta: Kementrian Pendidikan dan Kebudayaan, 2016), hlm. 2 


\begin{tabular}{|c|c|c|}
\hline B Indonesia & $\begin{array}{l}\text { 3.1 Mengenal teks deskriptif tentang } \\
\text { anggota tubuh dan pancaindra, } \\
\text { wujud dan sifat benda, serta } \\
\text { peristiwa siang dan malam dengan } \\
\text { bantuan guru atau teman dalam } \\
\text { bahasa Indonesia lisan dan tulis } \\
\text { yang dapat diisi dengan kosakata } \\
\text { bahasa daerah untuk membantu } \\
\text { pemahaman }\end{array}$ & $\begin{array}{l}\text { 4.1 Mengamati dan menirukan teks deskriptif } \\
\text { tentang anggota tubuh dan pancaindra, } \\
\text { wujud dan sifat benda, serta peristiwa siang } \\
\text { dan malam secara mandiri dalam bahasa } \\
\text { Indonesia lisan dan tulis yang dapat diisi } \\
\text { dengan kosakata bahasa daerah untuk } \\
\text { membantu penyajian }\end{array}$ \\
\hline PPKn & $\begin{array}{l}\text { 3.3 Mengenal keberagaman } \\
\text { karakteristik individu di rumah dan } \\
\text { di sekolah } \\
\text { 3.4 Mengenal arti bersatu dalam } \\
\text { keberagaman di rumah dan sekolah }\end{array}$ & $\begin{array}{l}\text { 4.3 Mengamati dan menceriterakan } \\
\text { kebersamaan dalam keberagaman di rumah } \\
\text { dan sekolah } \\
\text { 4.4 Mengamati dan menceriterakan } \\
\text { keberagaman karateristik individu di rumah } \\
\text { dan sekolah }\end{array}$ \\
\hline PJOK & $\begin{array}{l}\text { 3.3 Mengetahui konsep gerak dasar } \\
\text { manipulatif sesuai dengan dimensi } \\
\text { anggota tubuh yang digunakan, arah, } \\
\text { ruang gerak, hubungan, dan usaha, } \\
\text { dalam berbagai bentuk permainan } \\
\text { sederhana dan atau permainan } \\
\text { tradisional } \\
\text { 3.7 Mengetahui perbedaan bergerak di } \\
\text { air dan di darat dalam aktivitas air. }\end{array}$ & $\begin{array}{l}\text { 4.3 Mempraktikkan pola gerak dasar } \\
\text { manipulatif sesuai dengan dimensi anggota } \\
\text { tubuh yang digunakan, arah, ruang gerak, } \\
\text { hubungan, dan usaha, dalam berbagai } \\
\text { bentuk permainan sederhana dan atau } \\
\text { permainan tradisional. } \\
\text { 4.7 Mempraktikkan berbagai bentuk permainan } \\
\text { pengenalan air }\end{array}$ \\
\hline SBDP & $\begin{array}{l}\text { 3.4 Mengamati berbagai bahan, alat, } \\
\text { serta fungsinya dalam membuat } \\
\text { prakarya }\end{array}$ & $\begin{array}{l}\text { 4.2 Membuat karya seni ekspresi dengan } \\
\text { memanfaatkan berbagai teknik cetak } \\
\text { sederhana menggunakan bahan alam } \\
\text { 4.4 Membentuk karya seni ekspresi dari bahan } \\
\text { lunak } \\
\text { 4.14 Membuat karya kerajinan dari bahan alam } \\
\text { hasil limbah di lingkungan rumah melalui } \\
\text { kegiatan melipat, menggunting, dan } \\
\text { menempel }\end{array}$ \\
\hline $\begin{array}{c}\text { Untuk } \\
\text { komnetensi }\end{array}$ & $\begin{array}{l}\text { atema } 2, \text { pemetaan } \\
\text { ar dari KI } 1 \text { dan KI } 2 \\
\text { tabel berikut ini. }{ }^{70}\end{array}$ & \\
\hline
\end{tabular}

\begin{tabular}{|l|c|c|}
\hline SUBTEMA 2 & KI 1 & \multicolumn{1}{c|}{ KI2 } \\
\hline Matematika & & $\begin{array}{c}2.1 \text { Menunjukkan sikap cermat dan teliti, tertib } \\
\text { dan mengikuti aturan, peduli, disiplin } \\
\text { waktu serta tidak mudah menyerah dalam } \\
\text { mengerjakan tugas }\end{array}$ \\
\hline B Indonesia & $\begin{array}{c}\text { 1.2 Menerima keberadaan Tuhan Yang } \\
\text { Maha Esa atas penciptaan manusia } \\
\text { dan bahasa yang beragam serta } \\
\text { benda-benda di alam sekitar }\end{array}$ & $\begin{array}{c}\text { 2.1 Memiliki kepedulian dan rasa ingin tahu } \\
\text { terhadap keberadaan wujud dan sifat benda } \\
\text { melalui pemanfaatan bahasa Indonesia dan/ } \\
\text { atau bahasa daerah }\end{array}$ \\
\hline
\end{tabular}

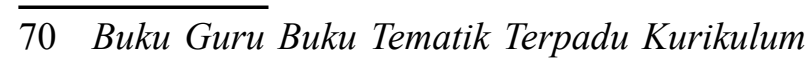
2013 Tema 7, Buku Guru SD/MI Kelas 1 (Jakarta: Kementrian Pendidikan dan Kebudayaan, 2016), hlm. 31 


\begin{tabular}{|c|c|c|}
\hline PJOK & $\begin{array}{l}\text { 1.1 Menghargai tubuh dengan seluruh } \\
\text { perangkat gerak dan kemampuannya } \\
\text { sebagai anugerah Tuhan yang tidak } \\
\text { ternilai }\end{array}$ & $\begin{array}{l}\text { 2.2 Bertanggung jawab terhadap keselamatan } \\
\text { diri sendiri, orang lain, dan lingkungan } \\
\text { sekitar, serta dalam penggunaan sarana dan } \\
\text { prasarana pembelajaran } \\
\text { 2.4 Menunjukkan kemauan bekerja sama } \\
\text { dalam melakukan berbagai aktivitas fisik } \\
\text { 2.7 Menerima kekalahan dan kemenangan } \\
\text { dalam permainan }\end{array}$ \\
\hline SBDP & $\begin{array}{l}\text { 1.1 Merasakan keindahan alam sebagai } \\
\text { salah satu tanda-tanda kekuasaan } \\
\text { Tuhan }\end{array}$ & $\begin{array}{l}\text { 2.1 Menunjukkan rasa percaya diri untuk } \\
\text { berlatih mengekspresikan diri dalam } \\
\text { mengolah karya seni } \\
\text { 2.2 Menunjukkan rasa ingin tahu untuk } \\
\text { mengenal alam di lingkungan sekitar } \\
\text { sebagai sumber ide dalam berkarya seni }\end{array}$ \\
\hline PPKn & $\begin{array}{l}\text { 1.2 Menerima kebersamaan dalam } \\
\text { keberagaman sebagai anugerah } \\
\text { Tuhan Yang Maha Esa di lingkungan } \\
\text { rumah dan sekolah }\end{array}$ & $\begin{array}{l}\text { 2.2 Menunjukkan perilaku patuh pada tata } \\
\text { tertib dan aturan yang berlaku dalam } \\
\text { kehidupan sehari-hari di rumah dan sekolah }\end{array}$ \\
\hline
\end{tabular}

Selanjutnya, pemetaan kompetensi

dasar dari KI 3 dan KI 4 dapat dijelaskan sebagai berikut. ${ }^{71}$

\begin{tabular}{|c|c|c|}
\hline SUBTEMA 2 & KI 3 & KI 4 \\
\hline B Indonesia & $\begin{array}{l}\text { 3.1 Mengenal teks deskriptif tentang } \\
\text { anggota tubuh dan pancaindra, } \\
\text { wujud dan sifat benda, serta } \\
\text { peristiwa siang dan malam dengan } \\
\text { bantuan guru atau teman dalam } \\
\text { bahasa Indonesia lisan dan tulis } \\
\text { yang dapat diisi dengan kosakata } \\
\text { bahasa daerah untuk membantu } \\
\text { pemahaman } \\
\text { 3.3 Mengenal teks terima kasih tentang } \\
\text { sikap kasih sayang dengan bantuan } \\
\text { guru atau teman dalam bahasa } \\
\text { Indonesia lisan dan tulis yang dapat } \\
\text { diisi dengan kosakata bahasa daerah } \\
\text { untuk membantu pemahaman }\end{array}$ & $\begin{array}{l}\text { 4.1 Mengamati dan menirukan teks deskriptif } \\
\text { tentang anggota tubuh dan pancaindra, } \\
\text { wujud dan sifat benda, serta peristiwa siang } \\
\text { dan malam secara mandiri dalam bahasa } \\
\text { Indonesia lisan dan tulis yang dapat diisi } \\
\text { dengan kosakata bahasa daerah untuk } \\
\text { membantu penyajian } \\
\text { 4.3 Menyampaikan teks terima kasih mengenai } \\
\text { sikap kasih sayang secara mandiri dalam } \\
\text { bahasa Indonesia lisan dan tulis yang dapat } \\
\text { diisi dengan kosakata bahasa daerah untuk } \\
\text { membantu penyajian }\end{array}$ \\
\hline Matematika & $\begin{array}{l}\text { 3.2 Mengenal bilangan asli sampai } 99 \\
\text { dengan menggunakan benda-benda } \\
\text { yang ada di sekitar rumah, sekolah, } \\
\text { atau tempat bermain } \\
\text { 3.12 Menentukan urutan berdasarkan } \\
\text { panjang pendeknya benda, tinggi } \\
\text { rendahnya tinggi badan, dan urutan } \\
\text { kelompok berdasarkan jumlah } \\
\text { anggotanya }\end{array}$ & $\begin{array}{l}\text { 4.3 Mengemukakan kembali dengan kalimat } \\
\text { sendiri dan memecahkan masalah yang } \\
\text { berkaitan dengan penjumlahan dan } \\
\text { pengurangan terkait dengan aktivitas } \\
\text { sehari-hari serta memeriksa kebenarannya } \\
\text { 4.8 Mengelompokkan teman sekelas } \\
\text { berdasarkan tinggi badannya }\end{array}$ \\
\hline
\end{tabular}

71 Buku Guru Buku Tematik Terpadu Kurikulum 2013 Tema 7, Buku Guru SD/MI Kelas 1, (Jakarta: Kementrian Pendidikan dan Kebudayaan, 2016), hlm. 31 


\begin{tabular}{|c|c|c|}
\hline PJOK & $\begin{array}{l}\text { 3.5 Mengetahui konsep berbagai } \\
\text { pola gerak dasar dominan statis } \\
\text { (bertumpu dengan tangan dan } \\
\text { lengan depan/ belakang/ samping, } \\
\text { bergantung, sikap kapal terbang, } \\
\text { dan berdiri dengan salah satu kaki), } \\
\text { serta pola gerak dominan dinamis } \\
\text { (menolak, mengayun, melayang } \\
\text { di udara, berputar, dan mendarat) } \\
\text { dalam aktivitas senam } \\
\end{array}$ & $\begin{array}{l}\text { 4.5 Mempraktikkan berbagai pola gerak } \\
\text { dominan dalam senam (seperti menolak, } \\
\text { mendarat, lokomotor, berputar, dan } \\
\text { mengayun) dan berbagai pola gerak } \\
\text { dominan posisi statis (misalnya; tumpu } \\
\text { lengan depan/ belakang/ samping, } \\
\text { bergantung, sikap kapal terbang, berdiri } \\
\text { dengan salah satu kaki) }\end{array}$ \\
\hline PPKn & $\begin{array}{l}\text { 3.2 Mengenal tata tertib dan aturan yang } \\
\text { berlaku dalam kehidupan sehari-hari } \\
\text { di rumah dan sekolah }\end{array}$ & $\begin{array}{l}\text { 4.2 Melaksanakan tata tertib di rumah dan } \\
\text { sekolah }\end{array}$ \\
\hline SBDP & $\begin{array}{l}\text { 3.1 Mengenal cara dan hasil karya seni } \\
\text { ekspresi } \\
\text { 3.4 Mengamati berbagai bahan, alat } \\
\text { serta fungsinya dalam membuat } \\
\text { prakarya }\end{array}$ & $\begin{array}{l}\text { 4.2 Membuat karya seni ekspresi dengan } \\
\text { memanfaatkan berbagai teknik cetak } \\
\text { sederhana menggunakan bahan alam } \\
\text { 4.7 Menyayikan lagu anak-anak dan berlatih } \\
\text { memahami isi lagu }\end{array}$ \\
\hline
\end{tabular}

Untuk Subtema 3 pemetaan

kompetensi dasar dari KI 1 dan KI 2 dapat

disajikan dengan tabel berikut. ${ }^{72}$

\begin{tabular}{|c|c|c|}
\hline SUBTEMA 3 & KI 1 & KI2 \\
\hline Matematika & & $\begin{array}{l}\text { 2.2 Memiliki rasa ingin tahu dan ketertarikan } \\
\text { pada matematika yang terbentuk melalui } \\
\text { pengalaman belajar } \\
\text { 2.3 Memiliki sikap objektif dan menghargai } \\
\text { pendapat dan karya teman sebaya dalam } \\
\text { diskusi kelompok maupun aktivitas sehari- } \\
\text { hari }\end{array}$ \\
\hline B Indonesia & $\begin{array}{l}\text { 1.2 Menerima keberadaan Tuhan Yang } \\
\text { Maha Esa atas penciptaan manusia } \\
\text { dan bahasa yang beragam serta } \\
\text { benda-benda di alam sekitar }\end{array}$ & $\begin{array}{l}\text { 2.1 Memiliki kepedulian dan rasa ingin tahu } \\
\text { terhadap keberadaan wujud dan sifat benda } \\
\text { melalui pemanfaatan bahasa Indonesia dan/ } \\
\text { atau bahasa daerah } \\
\text { 2.3 Memiliki perilaku santun dan sikap kasih } \\
\text { sayang melalui pemanfaatan bahasa } \\
\text { Indonesia dan/ atau bahasa daerah } \\
\text { 2.5 Memiliki perilaku santun dan jujur dalam } \\
\text { hal kegiatan dan bermain di lingkungan } \\
\text { melalui pemanfaatan bahasa Indonesia dan/ } \\
\text { atau bahasa daerah }\end{array}$ \\
\hline
\end{tabular}

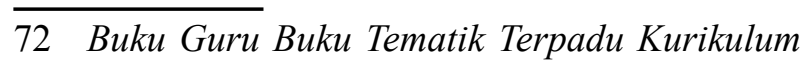
2013 Tema 7, Buku Guru SD/MI Kelas 1 (Jakarta: Kementrian Pendidikan dan Kebudayaan, 2016), hlm. 57 


\begin{tabular}{|c|c|c|}
\hline PJOK & $\begin{array}{l}\text { 1.1 Menghargai tubuh dengan seluruh } \\
\text { perangkat gerak dan kemampuannya } \\
\text { sebagai anugerah Tuhan yang tidak } \\
\text { ternilai }\end{array}$ & $\begin{array}{l}\text { 2.2 Bertanggung jawab terhadap keselamatan } \\
\text { diri sendiri, orang lain, dan lingkungan } \\
\text { sekitar, serta dalam penggunaan sarana dan } \\
\text { prasarana pembelajaran } \\
\text { 2.5 Toleransi dan mau berbagi dengan teman } \\
\text { lain dalam penggunaan peralatan dan } \\
\text { kesempatan } \\
\text { 2.6 Disiplin selama melakukan berbagai } \\
\text { aktivitas fisik }\end{array}$ \\
\hline PPKn & $\begin{array}{l}\text { 1.1 Menerima keberagaman } \\
\text { karakteristik individu dalam } \\
\text { kehidupan beragama sebagai } \\
\text { anugerah Tuhan Yang Maha Esa di } \\
\text { lingkungan rumah dan sekolah } \\
\text { 1.2 Menerima kebersamaan dalam } \\
\text { keberagaman sebagai anugerah } \\
\text { Tuhan Yang Maha Esa di lingkungan } \\
\text { rumah dan sekolah }\end{array}$ & $\begin{array}{l}\text { 2.1 Menunjukkan perilaku jujur, disiplin, } \\
\text { tanggung jawab, santun, peduli, dan } \\
\text { percaya diri dalam berinteraksi dengan } \\
\text { keluarga, teman, dan guru sebagai } \\
\text { perwujudan nilai dan moral Pancasila } \\
\text { 2.2 Menunjukkan perilaku patuh pada tata } \\
\text { tertib dan aturan yang berlaku dalam } \\
\text { kehidupan sehari-hari di rumah dan sekolah } \\
\text { 2.3 Menunjukkan perilaku kebersamaan dalam } \\
\text { keberagaman di rumah dan sekolah }\end{array}$ \\
\hline SBDP & $\begin{array}{l}\text { 1.1 Merasakan keindahan alam sebagai } \\
\text { salah satu tanda-tanda kekuasaan } \\
\text { Tuhan }\end{array}$ & $\begin{array}{l}\text { 2.1 Menunjukkan rasa percaya diri untuk } \\
\text { berlatih mengekspresikan diri dalam } \\
\text { mengolah karya seni } \\
\text { 2.2 Menunjukkan rasa ingin tahu untuk } \\
\text { mengenal alam di lingkungan sekitar } \\
\text { sebagai sumber ide dalam berkarya seni } \\
\text { 2.3 Menunjukkan perilaku disiplin, tanggung } \\
\text { jawab dan kepedulian terhadap alam sekitar } \\
\text { melalui BERKARYA SENI }\end{array}$ \\
\hline
\end{tabular}

Selanjutnya disajikan tabel pemetaan

kompetensi dasar dari Subtema 3 pada KI

3 dan KI $4 .{ }^{73}$

\begin{tabular}{|c|c|c|}
\hline SUBTEMA 3 & KI 3 & KI 4 \\
\hline Matematika & \begin{tabular}{|l|} 
3.7 Menentukan pola dari barisan \\
bangun datar sederhana \\
menggunakan benda-benda yang ada \\
di lingkungan sekitar \\
3.12 Menentukan urutan berdasarkan \\
panjang pendeknya benda, tinggi \\
rendahnya tinggi badan, dan urutan \\
kelompok berdasarkan jumlah \\
anggotanya
\end{tabular} & $\begin{array}{l}\text { 4.4 Mendeskripsikan, mengembangkan, dan } \\
\text { membuat pola yang berulang } \\
\text { 4.9 Mengumpulkan dan mengelola data } \\
\text { pokok kategorikal dan menyajikannya } \\
\text { dalam grafik konkrit dan piktograf tanpa } \\
\text { menggunakan urutan label pada sumbu } \\
\text { horizontal } \\
\text { 4.10 Membaca dan mendeskripsikan data } \\
\text { pokok yang ditampilkan pada grafik } \\
\text { konkrit dan piktograf }\end{array}$ \\
\hline
\end{tabular}

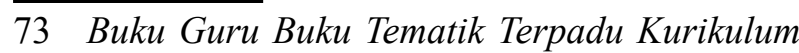
2013 Tema 7, Buku Guru SD/MI Kelas 1 (Jakarta: Kementrian Pendidikan dan Kebudayaan, 2016), hlm. 57 


\begin{tabular}{|c|c|c|}
\hline B Indonesia & $\begin{array}{l}\text { 3.1 Mengenal teks deskriptif tentang } \\
\text { anggota tubuh dan pancaindra, } \\
\text { wujud dan sifat benda, serta } \\
\text { peristiwa siang dan malam dengan } \\
\text { bantuan guru atau teman dalam } \\
\text { bahasa Indonesia lisan dan tulis } \\
\text { yang dapat diisi dengan kosakata } \\
\text { bahasa daerah untuk membantu } \\
\text { pemahaman } \\
\text { 3.3 Mengenal teks terima kasih tentang } \\
\text { sikap kasih sayang dengan bantuan } \\
\text { guru atau teman dalam bahasa } \\
\text { Indonesia lisan dan tulis yang dapat } \\
\text { diisi dengan kosakata bahasa daerah } \\
\text { untuk membantu pemahaman } \\
\text { 4.1 Mengamati dan menirukan teks } \\
\text { deskriptif tentang anggota tubuh } \\
\text { dan pancaindra, wujud dan sifat } \\
\text { benda, serta peristiwa siang dan } \\
\text { malam secara mandiri dalam bahasa } \\
\text { Indonesia lisan dan tulis yang dapat } \\
\text { diisi dengan kosakata bahasa daerah } \\
\text { untuk membantu penyajian }\end{array}$ & $\begin{array}{l}\text { 4.3 Menyampaikan teks terima kasih mengenai } \\
\text { sikap kasih sayang secara mandiri dalam } \\
\text { bahasa Indonesia lisan dan tulis yang dapat } \\
\text { diisi dengan kosakata bahasa daerah untuk } \\
\text { membantu penyajian }\end{array}$ \\
\hline PJOK & $\begin{array}{l}\text { 3.4 Mengetahui konsep bergerak secara } \\
\text { seimbang dan cepat dalam rangka } \\
\text { pengembangan kebugaran jasmani } \\
\text { melalui permainan sederhana dan } \\
\text { atau tradisional }\end{array}$ & $\begin{array}{l}\text { 4.4 Mempraktikkan aktivitas pengembangan } \\
\text { kebugaran jasmani untuk melatih } \\
\text { keseimbangan dan kecepatan tubuh } \\
\text { melalui permainan sederhanadan dan atau } \\
\text { tradisional }\end{array}$ \\
\hline SBDP & $\begin{array}{l}\text { 3.1 Mengenal cara dan hasil karya seni } \\
\text { ekspresi } \\
\text { 4.2 Membuat karya seni ekspresi } \\
\text { dengan memanfaatkan berbagai } \\
\text { teknik cetak sederhana } \\
\text { menggunakan bahan alam }\end{array}$ & $\begin{array}{l}\text { 4.7 Menyanyikan lagu anak-anak dan berlatih } \\
\text { memahami isi lagu }\end{array}$ \\
\hline PPKn & $\begin{array}{l}\text { 3.2 Mengenal tata tertib dan aturan yang } \\
\text { berlaku dalam kehidupan sehari-hari } \\
\text { di rumah dan sekolah }\end{array}$ & $\begin{array}{l}\text { 4.2 Melaksanakan tata tertib di rumah dan } \\
\text { sekolah }\end{array}$ \\
\hline
\end{tabular}

\section{Pelaksanaan Pembelajaran Tematik} dengan Konsep Agama Islam sebagai Agama Hijau

Pada subtema 1 dapat dilakukan pengukuran panjang pendek menggunakan pohon di sekitar sekolah. Juga dapat menggunakan daun, ranting dan sebagainya. Dapat pula mengukur tinggi rendahnya badan siswa di kelas.

Pada subtema 2: Hewan di Sekitarku disajikan bacaan "Hewan Peliharaan Beni". ${ }^{74}$

74 Sonya Sinyanyuri dan Lubna Assagaf, Buku Tematik Terpadu Kurikulum 2013, Buku Siswa SD/MI Kelas 1 (Jakarta, 2016), hlm. 49
Hewan peliharaan Beni adalah kucing. Sampai pada pembahasan ini, guru dapat menambahkan informasi bahwa Islampun sangat menganjurkan untuk menyayangi binatang, bahkan ada sahabat Rasul yang dijuluki Abu Hurairah yang artinya bapaknya kucing, karena sangat menyayangi kucing. Yaitu, suatu saat Abu Hurairah akan melaksanakan salat, dan pada sajadahnya ada seekor kucing yang sedang tidur, maka sajadah tersebut digunting tanpa mengganggu kucing yang sedang tidur tersebut. 
Pada saat mengamati dengan bahan bacaan "Tempat Tinggal Hewan""75, guru dapat mengajak siswa untuk memberikan contoh yang lebih bervariasi. Misalnya mengarahkan ke nama hewan: sapi, semut, lebah, laba-laba, anjing, dan sebagainya. Yang mana nama hewan-hewan tersebut diabadikan dalam nama surah Alqur'an, maupun dikisahkan dalam hadits.

Pelaksanaan pembelajaran dengan kompetensi matematika disesuaikan dengan buku siswa dan diselaraskan dengan lingkungan keseharian siswa.

Untuk pelaksanaan pembelajaran tematik subtema 3: Tanaman di Sekitarku, pada buku siswa diberikan bacaan "Merawat Tanaman". ${ }^{76}$ Pada pembelajaran ini, guru dapat menambahkan informasi bahwa dalam tuntunan Islam, sangat dianjurkan untuk merawat lingkungan termasuk tanaman. Dianjurkan untuk rajin menanam pohon. Dapat ditegaskan oleh guru bahwa merawat tanaman adalah perbuatan anak yang salih dan salihah. Pembelajaran matematika, dapat dilaksanakan dengan membawa peraga bijibijian, buah-buahan maupun sayur-sayuran untuk lebih mengkongkritkan, sehingga dapat membantu pemahaman siswa.

Ketika melakukan membaca nyaring dengan bahan bacaan "Membuat Sayur Sop Bersama Ibu"77 guru dapat menjelaskan bahwa dalam tuntunan agama Islam, sangat dianjurkan untuk memakan makanan yang sehat dan bergizi, atau dalam istilah Islam, dinyatakan dengan makanan yang halal

75 Sonya Sinyanyuri dan Lubna Assagaf, Buku Tematik Terpadu Kurikulum 2013, Buku Siswa SD/MI Kelas 1 (Jakarta, 2016), hlm. 49

76 Ibid. hlm. 90

77 Ibid. hlm. 125 dan tayyib. Sehat secara fisik maupun cara memperoleh dan mengolahnya.

\section{KESIMPULAN}

1. Islam sebagai agama hijau adalah agama yang mempunyai kepedulian terhadapa kelestarian lingkungan

2. Ayat-ayat hijau adalah ayat Alqur'an yang memperhatikan kelestarian lingkungan

3. Hadits hijau adalah hadits yang mereomendasikan tentnag perilaku peduli lingkungan

4. Pembelajaran tematik matematika dengan mata pelajaran lain dirancang pada kelas 1 tema 7

5. Pada subtema 2: Hewan di sekitarku guru dapat menginformasikan surah-surah dalam Alqur'an yang dinamai dengan nama-nama binatang

6. Pada subtema 3: Tanaman di sekitarku, guru dapat menginformasikan bahwa banyak hadits yang merekomendasikan untuk menyayangi tanamn dan rajin menanam pohon

7. Pembelajaran matematika dapat menggunakan peraga buah-buahan, bijibijian dan melaksanakan pengukuran panjang pendek menggunakan pohon maupun bagian-bagiannya.

\section{DAFTAR PUSTAKA}

Agung Prihatmiko. (1994), “Akuntasi Hijau: Penelaahan atas Akuntansi Biaya Lingkungan”, Jakarta: Skripsi STAN.

Ananda Putri. (2016), Aksi hijau memikat dari para pegiat lingkungan; SWA. Green Business Great Profit.

Gatot Muhsetyo. (2009), Pembelajaran Matematika SD. Jakarta: Universitas Terbuka. 
Green Building Council Indonesia. (2011), Green Rating Tools untuk Gedung Terbangun Versi 1.0, Jakarta.

Ibrahim Abdul Matin. (2010), Green Deen, terjemahan, Jakarta: Penerbit Serambi Ilmu Semesta.

Ibrahim \& Suparni. (2008), Strategi pembelajaran matematika. Yogyakarta: Fakultas Saintek UIN Sunan Kalijaga.

John P Surma dan Albert A. Vondra. (1992), Accounting for Environmental Cost, a Hazardous Subject. Journal of Accountancy.

Kamaruzaman Jusoff dan Siti Akmar Abu Samah. (2011), "Environmental Sustainability: What Islam Propagates"; World Applied Sciences Journal 12 (Special Issue on Creating a Knowledge Based Society).

Kementerian Pendidikan dan Kebudayaan. (2013), Tematik Terpadu Kurikulum 2013.Untuk SD/MI Kelas IV. (Jakarta: Kementerian Pendidikan dan Kebudayaan).

Kennedy, L. M., Tipps, S., \& Johnson, A. (2008), Guiding children's learning of mathematics, (Belmont: Thomson Wadsworth).

Marsigit. (2009), "Pembudayaan matematika di sekolah untuk mencapai keunggulan bangsa." (Yogyakarta: Makalah Seminar Nasional Pembelajaran Matematika Sekolah (FMIPA UNY)).

Office of Sustainable Development Bureau for Africa. (2000), Lessons From SchoolBased Environmental Education Programs in Three African Countries, (Mfuwe, Zambia).
Punaji Setyosari, (2010), Metode Penelitian Pendidikan Dan Pengembangan, (Malang: Kencan Purnama Media Group).

Rami Killawi. (2014), Sustainable Development in Islamic Perspective (Dubai).

Reys, R.E, Suydam, M.N, Lindquist, M.M, et al. (1998), Helping Children Learn Mathematics. (Fifth edition) (Boston: Allyn and Bacon).

Sonya Sinyanyuri dan Lubna Assagaf. (2016), Buku Tematik Terpadu Kurikulum 2013, Buku Siswa SD/MI Kelas 1 (Jakarta: Kemendikbud)

Sugiyono. (2008), Statistika untuk Penelitian (Bandung: Alfabeta).

Sugiyono. (2009). Metode Penelitian Kuantitatif Kualitatif dan $R \& D$ (Bandung: Aflabeta).

Suharso. (2010), Kamus Besar Bahasa Indonesia. (Semarang: CV Widya Karya).

SWA (2016), Green Business Great Profit (Jakarta). 